NBER WORKING PAPER SERIES

\title{
WHAT YOU DON'T KNOW CAN'T HELP YOU: PENSION KNOWLEDGE AND RETIREMENT DECISION MAKING
}

\author{
Sewin Chan \\ Ann Huff Stevens
}

Working Paper 10185

http://www.nber.org/papers/w10185

\author{
NATIONAL BUREAU OF ECONOMIC RESEARCH \\ 1050 Massachusetts Avenue \\ Cambridge, MA 02138 \\ December 2003
}

We thank seminar participants at Syracuse University, UC Santa Cruz, the NBER Labor Studies group, and Ron Miller for helpful comments and suggestions. This research was supported by a grant from the U.S. Social Security Administration (SSA) to the Center for Retirement Research at Boston College through the Steven H. Sandell Grant Program. The opinions and conclusions are solely those of the authors and should not be construed as representing the opinions of SSA or any agency of the Federal Government. The views expressed herein are those of the authors and not necessarily those of the National Bureau of Economic Research.

(C)2003 by Sewin Chan and Ann Huff Stevens. All rights reserved. Short sections of text, not to exceed two paragraphs, may be quoted without explicit permission provided that full credit, including (C) notice, is given to the source. 
What You Don't Know Can't Help You: Pension Knowledge and Retirement Decision Making Sewin Chan and Ann Huff Stevens

NBER Working Paper No. 10185

December 2003

JEL No. J2

\section{$\underline{\text { ABSTRACT }}$}

This paper provides an answer to an important empirical puzzle in the retirement literature: while most people know little about their own pension plans, retirement behavior is strongly affected by pension incentives. We combine administrative and self-reported pension data to measure the retirement response to actual and perceived financial incentives. We find that well-informed individuals are five times more responsive to pension incentives than the average individual when knowledge is ignored. We further find that the ill-informed individuals do respond to their own misperception of the incentives, rather than being unresponsive to any incentives.

\section{Sewin Chan}

Wagner Graduate School of Public Service

New York University

New York, NY 10012

sewin.chan@nyu.edu

Ann Huff Stevens

Department of Economics

One Shields Avenue

University of California, Davis

Davis, CA 95616

and NBER

annstevens@ucdavis.edu 
This paper addresses an important empirical puzzle in the retirement literature: while most people do not know the details of their own pension plans, retirement behavior is strongly affected by pension incentives. The answer we find is intuitive: people respond to incentives that they know about. Estimated responses of retirement to financial incentives are driven by a minority of the population who are well-informed about those incentives. Our empirical approach combines administrative and self-reported pension data to measure the retirement response to actual and perceived financial incentives. We find that uninformed people show no response to their actual retirement incentives while well-informed people respond much more than previously thought.

Understanding how responsiveness to pension incentives is related to knowledge of these incentives is important for policy discussions. Virtually all of the recent empirical research on responsiveness to financial retirement incentives is based on administrative data, and several recent studies use their estimates to simulate or forecast the response to policy changes such as altering the normal retirement age or benefit levels. ${ }^{1}$ While such estimates may accurately capture an average effect, we find that this average masks a tremendous amount of heterogeneity in individual responsiveness that is directly related to individuals' knowledge of pension incentives. Because alternative policy changes and their specific implementation will almost certainly be associated with different levels of transparency and public knowledge, we need to understand how this knowledge interacts with the incentives in order to accurately predict which types of individuals are most likely to respond and what their responses will be.

Our findings also have important implications beyond understanding retirement behavior.

\footnotetext{
${ }^{1}$ For example, see Coile and Gruber (2000), or Samwick (1998).
} 
While much applied economic research seeks to measure the responsiveness of individuals to certain incentives, we are aware of no other study that has made such a direct comparison between the responsiveness to self- and administratively-reported measures of incentives. The issues raised in this study are relevant to a variety of economic policies. For example, would individuals respond more strongly to the various tax-favored savings vehicles if they knew what these complex incentives are ${ }^{2}$ The earned income tax credit (EITC) is another example in which knowledge may be a crucial determinant of responsiveness; would workers respond differently to the EITC if they realized the precise marginal tax rate at each level of earnings? At a minimum, our results suggest that heterogeneity in individual knowledge can lead to significant heterogeneity in responses. The availability of self- and administratively-reported pension data provides a unique opportunity to quantify the extent to which individuals' lack of information contributes to reduced responsiveness to economic incentives.

Our analysis below uses self-reported, employer-reported and Social Security Administration data from the Health and Retirement Study (HRS). To examine the relationship between knowledge of retirement benefits and individuals' responsiveness to those benefits, we begin by calculating two versions of financial retirement incentives, one based on self-reported data, and another based on employer-reported or administrative data. It is straightforward to show that both versions of these incentives affect retirement, and that the self-reports continue to be strongly significant determinants of retirement even after controlling for the employer reports. We then use the self-reports to construct summary measures of individuals' knowledge of their pension plans. When these knowledge measures are interacted with the incentives based on employer-provided data, we show that the better-informed fraction of the population generates

\footnotetext{
${ }^{2}$ Recent work by Duflo and Saez (2002), further described below, suggests the answer to this question is yes.
} 
all of the average response to pension incentives, and that the ill-informed segment of the population show no significant response. We further show that this ill-informed population is not completely unresponsive to any incentives, but rather, they are responsive to their own misperception of the incentives. Finally, we demonstrate that our main results are robust to a simple selection model.

Our analyses draw upon two strands of the recent retirement literature. The first of these includes studies that examine the extent of information that individuals possess about their future retirement benefits. The common finding across these studies is that such information is typically quite incomplete. The work of Gustman and Steinmeier (2001a, 2001c) using the HRS sets the stage for our work. ${ }^{3}$ They examine the determinants of knowledge of Social Security and private pensions, and the implications of this knowledge for retirement planning. They find, for example, that only half of respondents can correctly identify the type of pension plan (defined benefit versus defined contribution) in which they participate, and that age, union membership, longer planning horizons and certain retirement planning activities signal individuals who are better informed about their pensions. In addition, they find that workers who initially overestimate their available benefits retire later than they had originally planned.

A related part of the literature shows the potential for behavioral responses to interventions that alter individuals' information sets. Duflo and Saez (2002) demonstrate that small incentives that encourage individuals to learn more about retirement savings vehicles can have significant effects on participation in retirement savings plans. Their results echo the

\footnotetext{
${ }^{3}$ Other studies include Mitchell (1988) who uses pension information provided by employers and workers in the 1983 Survey of Consumer Finances, and Luchak and Gunderson (2000) who examine pension information among employees of a unionized public utility industry in Canada.
} 
earlier findings by Bernheim and Garrett (1996) that show large effects of financial education on individual savings and other behavior.

Also related to the lack of knowledge about pension incentives is work by Choi, Laibson, Madrian and Metrick (2001). They find that employees tend to follow the "path of least resistance" and that the default options in an employers' pension plan have a major impact on participation in the plan and on the participants' saving behavior and investment portfolio. While this is not evidence of a lack of knowledge per se, it is certainly consistent with individual behavior that does not pay much attention to knowing or caring about finances and financial incentives.

The second strand of relevant literature includes virtually all studies that examine the effects of private pension incentives on retirement and much of the related work on Social Security incentives. Many papers have utilized data taken from employer-reports or administrative sources and they have generally found that individuals are quite responsive to the financial incentives embedded in pension plans and Social Security. Stock and Wise (1990), and Lumsdaine, Stock and Wise (1992) estimate both structural and reduced-form models of the retirement decision using data provided by a single large employer. Samwick (1998) uses the employer-provided data on private pensions from the Survey of Consumer Finances to estimate a regression-based counterpart to existing structural models of retirement, focusing on the role of forward-looking financial retirement incentives, or "option value" in determining the probability of retirement. In a similar approach, both Coile and Gruber (2000) and Gustman and Steinmeier (2001b) use employer-provided pension data, along with administrative records of Social Security earnings histories to estimate the effect of private pensions and Social Security on retirement. Our analyses below is the first to provide a direct link between this literature that 
uses administrative data to study retirement behavior, and the growing evidence that many of these incentives are not well understood by the individual's whose decisions we are modeling.

A possible explanation for why individuals seem to respond to incentives that they do not apparently know is that individuals do know but self-reported pension data are so inaccurately measured that they provide a misleading picture of individual knowledge. We present evidence below that this is unlikely to be the case. While it is almost certainly true that self-reported pension data are measured with some error, financial incentive measures based on these selfreported data are significant predictors of retirement behavior, even after conditioning on incentives based on administrative data. This confirms results from Chan and Stevens (2002, 2003) that finds after controlling for earlier retirement expectations or individual-specific fixed effects, the self-reported financial incentives are still important determinants of retirement behavior.

Thus, another key contribution of this paper is to demonstrate that self-reported data, while largely ignored by economists when administrative data are available, do provide relevant information. This is an important finding given the extensive effort devoted to the collection of self-reported data, and the rarity with which some of these data have been used by economists to study behavior. If self-reported data are truly so poorly measured as to be uninformative, that would raise questions of whether they should continue to be collected. However, as we illustrate below in the case of retirement decision-making, the self-reported data are extremely useful in understanding how these decisions are made.

\section{Data and Samples}


We use data from the first four waves of the Health and Retirement Study (HRS), including: (i) the self-reported, publicly released data on retirement income sources, retirement behavior, and retirement expectations, (ii) the employer-provided pension plan details, and (iii) the Social Security earnings histories, which allow us to calculate individuals' Social Security benefits at alternative future retirement dates. Several points should be made regarding these data sources.

First, the employer-provided pension data are available only for jobs held at or before wave 1 of the survey, while self-reported pension data are available for all waves. Similarly, the administrative earnings histories include Social Security covered earnings only up to the initial wave. However, it is possible to use the employer-provided data to judge the accuracy of selfreported private pension information because job changes are not very frequent at this age range. Individuals who do change employers before retirement are dropped from our samples, as is the small fraction of individuals who report changes to their pension plans between waves. ${ }^{4}$ The wage histories from Social Security records can be supplemented with self-reported earnings in subsequent years so that Social Security benefits can be calculated for later waves as well. Because of this projection of the administrative data to subsequent waves, we control for the survey wave in our analysis and compare results across the initial and later waves.

Second, we follow many previous researchers in assuming that the employer and Social Security administrative data represent the true benefit information. In some cases, particularly with respect to the employer reports, this assumption may not be accurate. For defined contribution pension accounts in particular, there are good reasons to expect that the employer

\footnotetext{
${ }^{4}$ Individuals are asked whether there have been any changes to their pension plans since the previous survey. They are then asked about the details of their pensions, even if they report no change since the previous wave.
} 
reports could deviate from the truth (Uccello and Perese, 1999). Thus, in the case of defined benefit plans, we are more confident about relying on the employer reports as the "true" pension. Throughout the analysis, we have also examined the sub-sample of workers with defined benefit plans to investigate whether our results differ systematically across pension plan types and find little evidence of such differences. ${ }^{5}$

Third, while the self-reported data are useful because they reflect what individuals actually know, many researchers have expressed concerns that such data may contain substantial measurement error. These pension reports may differ from the employer reports not only because individuals do not know the information, but also because they misreport this information. While this is certainly a concern, we believe that the potential importance of understanding how knowledge affects retirement decision-making overrides the concern about measurement error. Indeed, our results described below demonstrate that there are large and statistically significant differences between informed and uninformed individuals. These differences may be understated if our measures of knowledge are severely affected by measurement error.

Using the self- and employer-reported data on pensions, our first step is to take the pension plan details and use them to construct the present value of pension wealth available to the individual at each possible future retirement age. Following previous literature, we construct financial incentive measures that are based on the difference between: (i) the present value of pension wealth if an individual retires at the future date that maximizes his or her present value

\footnotetext{
${ }^{5}$ There is also potential for measurement error in the administrative reports because measures of individuals' years of service with their employer (often a key component in retirement-age-specific pension value calculations) are taken from the self-reported HRS data in transforming the employer-provided pension plans into measures of pension wealth.
} 
of pension wealth, and (ii) the present value of pension wealth if an individual retires today. We refer to this measure as an individual's "pension gain":

[1] GAIN $_{i t}=\mathrm{PV}\left(\right.$ pension wealth if $R=\operatorname{argmax}_{(\mathrm{t}+1-\infty)}[\mathrm{PV}($ pension wealth $\left.)]\right)$

- PV (pension wealth if $R=t$ )

where GAIN $_{i t}$ is the pension gain of individual $i$ at time $t$, and $R$ is the retirement date. ${ }^{6}$

For individuals self-reporting defined benefit (DB) pensions, we have information on annual benefit amounts, the normal retirement (pension eligibility) age, the early retirement age, cost of living adjustments, and benefit reduction amounts in the case of early retirement from each survey wave. For those reporting defined contribution (DC) pensions, we have information on the current account balance, employer- and own-contributions, and basic portfolio allocation decisions for existing DC accounts. These pieces of data are combined to generate estimates of the present value of pension wealth at each possible retirement age. The employer-provided reports, while more detailed, contain similar information for each pension plan. In calculating the present discounted value of pension wealth at each retirement age, we assume a discount factor of 3\%, and weight future values by age- and gender-specific survival probabilities taken from Social Security Administration actuarial tables.

Table 1 shows summary statistics for our sample. To be included in the analyses, individuals must have an employer-reported pension plan, and cannot yet be retired at the time of the wave 1 survey. We consider the probability of retirement at each different age between the wave 1 and wave 4 surveys. Observations from the wave 1 survey are excluded, since (by our

\footnotetext{
${ }^{6}$ This is similar to the option value concept used in Lumsdaine, Stock and Wise (1992), and Samwick (1998), equivalent to the "peak value" used by Coile and Gruber (2000) and related to the "premium value" used by Gustman and Steinmeier (2001b).
} 
sample definition) all retirements occur following wave 1 . Individuals remain in the sample through wave 4 , or until they retire. Roughly 13 percent of all observations reflect a retirement in the current year, while 34 percent of individuals in our sample have retired by the time of the wave 4 survey. Slightly more than half of the sample is male, and the average age is just over 58 years. The sample includes 5 percent Hispanic respondents and 16 percent black respondents. More than three-quarters of the sample members are married.

The lower section of Table 1 provides means for key summary measures of pension wealth, based on both self- and employer-reports. The average level of pension wealth (assuming the individual retires in the current year) is approximately $\$ 69,000$ (in 1992 dollars) based on self-reports, but is more than $\$ 153,000$ based on the employer-reports. The average pension gain (the present value of pension wealth if retirement occurs at the wealth-maximizing age minus the present value if retirement occurs today) is somewhat higher in the self-reports: $\$ 56,534$ versus $\$ 25,152$ from the employer-reports. However, if we consider median values of pension gain, this ranking is reversed: the median pension gain based on self reports is $\$ 0$, while the median pension gain from employer reports is $\$ 11,545$.

Table 2 presents some summary statistics of variables intended to describe the accuracy of individuals' self-reported pension values. First, following the basic strategy of Gustman and Steinmeier (2001a), we consider whether individuals report "don't know" when asked about the value of their pension. Specifically, we construct a variable, REPORT, that is equal to one for individuals who report enough of the key components of their pension plans to allow us to 
construct the present value of benefits at various possible retirement ages. ${ }^{7}$ If individuals report not knowing some major component of their pension, REPORT is set equal to zero. As noted by Gustman and Steinmeier, a large fraction of individuals report not knowing the value of their pension. As shown in Table 2, 63 percent of our sample have REPORT equal to one.

An alternative measure used in previous work is to compare the present value of an individual's level of pension wealth based on the self-report with that based on the administrative report. ${ }^{8}$ To implement this, we create a variable $K N O W_{-} L E V E L$ that is equal to one if (i) the ratio of the self-reported to employer-reported pension wealth is between 0.5 and 2 , or (ii) one of the reported pension wealth values is zero and the other is less than $\$ 5,000$. The second component of this definition is included to avoid misclassifying as uninformed those who report zero wealth rather than very small amounts of pension wealth. For those who do not report enough information on their pension to calculate the value of pension wealth $(R E P O R T=0)$, we set $K N O W_{-} L E V E L$ equal to zero. We do this also for similar variables discussed below. Among those with REPORT equal to one, Table 2 shows that 51 percent of our sample report levels of pension wealth relatively close to those based on the employer reports.

Because we are primarily interested in individuals' knowledge of the financial incentive to retire inherent in their pension structure, we use a third measure that captures the accuracy of individuals' knowledge of their pension gain. After calculating each individual's pension gain using both self- and employer-reported values, the variable $K N O W \_G A I N$ is set equal to one if

\footnotetext{
${ }^{7}$ These key components for defined benefit plans include normal and early retirement ages, benefit amounts per year, and benefit reduction rates for early retirement. For defined contribution plans we require current account balances, along with own and employer contributions per year.

${ }^{8}$ Gustman and Steinmeier (2001), for example, create a variable equal to one if the self-report is within 25 percent of the administrative report of pension wealth.
} 
the ratio of pension gain based on self- and employer- reports is between 0.5 and 2 , or if one is zero and the other is within $\$ 5,000$. Table 2 shows that 27 percent of our sample are wellinformed regarding this more complex measure of the incentive effects of pensions. This measure requires individuals to understand benefit eligibility ages, amounts and reductions at alternative hypothetical retirement ages.

The second and third columns of Table 2 split the sample into those with and without an active defined benefit plan (based on the employer-report). ${ }^{9}$ For both $R E P O R T$ and $K N O W_{-} L E V E L$, those with a DB plan are more knowledgeable than those without. However, when the knowledge measure is based on knowing actual pension gain (KNOW_GAIN), individuals with a DB plan are far less likely to be informed. This is not surprising since DB plans are usually associated with a more complex incentive structure.

Finally, we construct a measure of knowledge that captures whether individuals simply understand the sign of their pension gain. KNOW_SIGN is equal to one if the employer- and self-reports of pension gain are both positive, both negative, or if both are equal to zero. Fiftyfive percent of individuals reporting key pension values have self-reports that lead to a pension gain of the same sign as the employer-report.

The knowledge measures that include Social Security are constructed in a similar fashion to those for private pensions only. Unfortunately, the self-reported data on expected Social Security benefits are much less extensive than the self-reported pension data. Specifically, individuals are asked only for their expected Social Security benefit amount at their expected retirement age. Thus, for Social Security, we can only create a knowledge measure, KNOW_SS, that indicates whether the expected level of benefits at that expected retirement age is close to the

\footnotetext{
${ }^{9}$ Some workers excluded from this column may have defined benefit plans from previous employers.
} 
level we calculate from Social Security Administration data. It is not possible to construct a measure similar to KNOW_GAIN for Social Security benefits. Another limitation is that only a single respondent per household was asked to provide expected benefit information. To avoid using a spouse's knowledge of Social Security benefits to determine an individual's behavior, we include only those individuals who directly report their own expected Social Security benefit in this analysis. Just 40 percent of the sample report their anticipated Social Security benefits, with most of the missing reports the result of the relevant household member not being asked the question. Among the subsample providing information on expected Social Security benefits, more than three-quarters are reasonably accurate in their expected benefit level.

\section{Empirical Strategy and Results}

\section{A. Comparing the Effect of Self- and Administratively-Reported Financial Retirement Incentives on Retirement}

We begin by directly comparing the effect of financial retirement incentives, calculated from employer- and self-reported pension data. Following much recent empirical work, we estimate a retirement equation described by:

$$
R_{i t}=\beta_{0}+\beta_{1} G A I N_{i t}+X_{i t} \beta+\varepsilon_{i t}
$$

where $R_{i t}$ is a binary variable indicating that the individual $i$ retires in year $t$, and $\varepsilon$ is an error term. GAIN ${ }_{i t}$ represents the pension gain to continued work, as defined above, based on employer-reported pension data. Samwick (1998) and Coile and Gruber (2000) show that forward-looking measures such as pension gain have greater explanatory power than alternative myopic summary measures of financial status or incentives. $X_{i t}$ is a vector that contains several 
important control variables, including age, demographic characteristics, calendar years, and measures of non-pension wealth and lifetime earnings. ${ }^{10}$

The first column of Table 3 shows the effects of pension gain from the employer-reports on the probability of retirement using a probit model and all sample observations. Other variables included in these specifications are race, education, sex, self-reported health status, marital status, dummy variables for age, level of non-pension assets, a measure of average lifetime earnings, and dummies for the survey wave. ${ }^{11}$ In results not reported, we have also included indicators for retiree health insurance and an insurance indicator interacted with poor health. Adding these controls does not change our basic results and they are excluded here because of a larger number of missing values for the retiree health insurance variables. Standard errors have been corrected to account for repeated observations from the same individual across survey waves. We present results for men and women pooled, although we have also obtained similar results when we estimate separate regressions for men and women.

As expected, the pension gain variable is negative and significant, implying that a larger gain to delaying retirement until a future optimal date reduces the likelihood of retirement. The estimated coefficient of -0.0179 shown in the first column implies that a $\$ 10,000$ increase in pension gain would reduce the probability of retirement by approximately a quarter of a

\footnotetext{
${ }^{10}$ See Coile and Gruber (2000) for a discussion of the importance of carefully controlling for measures of lifetime earnings. It is also crucial to control fully for age because there are spikes and non-linearities in the age profile of retirement probabilities and because knowledge may also be correlated with age. Thus, we include a series of dummy variables for each year of age (51 to 70) in our sample.

${ }^{11}$ While none of the regression results shown in the paper use the HRS sampling weights, we have estimated all specifications using these weights and find no substantive differences in our results from weighting.
} 
percentage point, or 3 percent. ${ }^{12}$ This magnitude is very close to that reported by Coile and Gruber (2000) for a similar measure including both pensions and Social Security. As in some earlier research, we find that the level of pension wealth (if retirement occurs immediately) has a positive and significant effect, suggesting that those with higher levels of pension wealth are more likely to retire. ${ }^{13}$ The magnitude of this pension wealth effect, also similar to previous work, is quite small, with a $\$ 10,000$ increment to pension wealth increasing retirement by less than one-tenth of a percentage point.

In the next column, we repeat the exercise, but restrict the sample to individuals who have valid self-reports of their pensions $(R E P O R T=1)$. The coefficient on pension gain rises slightly, but is not significantly different from that in the first column, suggesting that restricting the sample to those with valid self-reported pension values does not systematically alter the response to pension incentives.

In the third column of Table 3, we use pension gain and pension wealth variables based on individuals' self-reports. The coefficient on pension gain based on the self-reports is very close to the comparable coefficients based on employer reports and is statistically significant. In the fourth column, we include both the self- and employer-based versions of pension gain and pension wealth levels. The correlation between the two measures of pension gain is 0.22 . When

\footnotetext{
${ }^{12}$ Marginal reported effects are shown in italics below the standard errors in the tables and are calculated for a 60 year old, married, white male, with some college education, observed in wave 2, and with all continuous variables set to their mean values.

${ }^{13}$ We should note that some other previous work has not found a significant effect of the level of pension wealth on retirement probabilities. Samwick (1998), for example, finds that the level of pension wealth has no effect on retirement once a forward-looking incentive measure is included in the model. Overall, however, these basic results are consistent both with theoretical predictions and with previous empirical work.
} 
both are included together (in column 4), the self-reported pension gain variable remains statistically significant and is somewhat larger in magnitude than the employer-reported variable. This indicates that, rather than being dominated by noise, the self-reported data contain important information relevant for individual decision-making. For pension wealth levels, the employer-reported data remain statistically significant (although quite small), while the selfreported version does not.

\section{B. Exploring Heterogeneity in Responsiveness to Financial Retirement Incentives}

We next document differences in the responsiveness of individuals to financial incentives based on a variety of measures of their understanding of these incentives. To capture this possible heterogeneity, we modify [2] to allow a differential response by the knowledge of pension incentives:

$$
R_{i t}=\alpha_{0}+\alpha_{1} \text { GAIN }_{i t}+\alpha_{2} \text { INFORMED }_{i t}+\alpha_{3} \text { GAIN }_{i t} * \operatorname{INFORMED}_{i t}+X_{i t} \beta+\varepsilon_{i t}
$$

where, as before, $R_{i t}$ is a binary variable indicating that the individual $i$ retires in year $t, G A I N_{i t}$, is the pension gain to continued work based on employer-reported pension data, and $\varepsilon$ is an error term. With the exception of the terms associated with coefficients $\alpha_{2}$ and $\alpha_{3}$, this specification is identical to that used in previous work. INFORMED $i t$ is one of the variables described above (and summarized in Table 2) that attempts to capture the extent of individuals' knowledge of their pension benefits.

Probit estimates of [3] are shown in Table 4. For ease of comparison, the first column replicates the results from the first column of Table 3 and shows the negative and statistically significant effect of pension gain on the probability of retirement when knowledge is ignored. Marginal effects implied by the probit coefficients are shown at the bottom of the table, along 
with the change in the retirement probability implied by the dummy variables for our various measures of information.

In column 2 of Table 4, we show that REPORT=1 (knowing, or at least reporting some guess of, the key components of a pension plan) is associated with an increased probability of retirement. Reporting all of the key pension plan values is associated with an annual probability of retirement that is approximately 4 percentage points higher. This may reflect reverse causality: individuals who are actively considering retirement may be more likely to know enough to report some values for their pension plan. There is no significant interaction between this information measure and pension gain.

Column 3 of Table 4 displays results using $K N O W \_L E V E L$ (being reasonably wellinformed about the level of pension wealth). These results suggest that individuals with better knowledge of their pension plans may show a greater responsiveness to pension-related incentives in making the retirement decision. The total effect of pension gain is statistically significant only for well-informed individuals (pension gain plus $K N O W \_L E V E L *$ pension gain). However, the interaction between $K N O W \_L E V E L$ and pension gain is not itself statistically different from zero.

In column 4 of Table 4, we use KNOW_GAIN (being reasonably well-informed about the size of pension gain) and its interaction with pension gain. This specification produces much stronger evidence of heterogeneity in responsiveness to pension incentives, as we would expect since pension gain itself is the measure of the incentive to retire. The main coefficient on pension gain, capturing the effect of employer reported pension gain for individuals whose selfreports are substantially different than their employer reports (or who do not report enough information to construct it), is very small and no longer statistically significant. The interaction 
between pension gain and $K N O W \_G A I N$, however, is significant and implies a marginal effect that is over five times as large as the coefficient on pension gain by itself in column 1 . This suggests that all of the responsiveness to pension incentives is driven by the roughly 20 percent of the sample who correctly perceive the incentive to delay retirement. Among individuals who meet this definition of informed, a $\$ 10,000$ increase in pension gain raises the annual probability of retirement by 1.4 percentage points, or nearly 20 percent. The main effect of KNOW_GAIN is also large and statistically significant; individuals who know their pension gain are 4 percentage points more likely to retire in a given year.

Columns 5 and 6 of Table 4 repeat some of the above analysis using the measure of GAIN constructed from both pensions and Social Security. As noted above, the sample size is dramatically reduced when we require both self- and administratively-reported data on Social Security. The coefficient on GAIN combining both pension and Social Security benefits in column 5 is slightly smaller than the effect of pension incentives alone, and is statistically significant. However, knowledge of the level of these Social Security benefits is not significantly related to retirement behavior: neither the main effect nor the interaction effect is statistically significant. We view this result primarily as a reflection of the limited data we have available on individuals' knowledge of their Social Security benefits.

Finally, in columns 7 and 8, we show results based on the sample of individuals with a defined benefit pension. Our employer-reported pensions are more likely to represent the true pensions for this sub-sample. In addition, most of our identifying variation in pension gain is generated by defined benefit pension plans. These results are similar to those for the full sample. Results based on individuals without an active defined benefit pension (not shown in the table) are also similar, though less precisely estimated. This reflects the fact that most of the 
identification of the pension gain coefficient is coming from defined benefit pensions, for which pension gain takes on a wider range of values at different ages.

We have also tried specifications in which we drop from the sample individuals who do not report enough information to form a self-reported measure of pension gain (REPORT $=0$ and thus, INFORMED=0). This allows us to distinguish between individuals who simply do not report information on their pensions and those who report values that are very different from their employer-reports. These coefficients are very similar to those reported in Table 3.

We have explored several alternative definitions of the knowledge variables. In particular, we tried altering the definition of $K N O W_{-} G A I N$ to allow for different degrees of error in determining who knew their pension gain accurately. For example, we considered definitions in which the ratio of self- to employer-reported pension gain was between 0.75 and 1.25 , and other cut-offs. The coefficients on KNOW_GAIN were not sensitive to these cutoffs. This suggested that individuals were responding to something other than the precise dollar values of their pension gain. One possibility is that individuals retire when they face a zero gain or a loss from continuing to work. If this is the case, it may be enough if individuals simply understand the sign of their pension gain. To explore this possibility, we use KNOW_SIGN (knowing the sign of pension gain) as the measure of pension knowledge.

The results of interacting $K N O W \_S I G N$ with pension gain are shown in Table 5. Column 1 simply repeats the first column of Tables 3 and 4 for ease of comparison. In column 2, we show that there is no statistically significant response to pension gain among the roughly twothirds of the sample who do not know whether they stand to gain or lose pension wealth from continuing to work. In contrast, those who know the sign of pension gain have the expected negative and significant response to the financial incentive measure, and again, the magnitude of 
their response is over five times that of the average response to pension gain from column 1.

Finally, given that the sign of pension gain appears to be an important piece of individual knowledge, we consider whether the sign alone can explain retirement behavior as well as the continuous measure. In column 3 of Table 5 we show results of a model of retirement in which dummies for negative and zero pension gain are included (the omitted category is positive pension gain). The dummy for a negative pension gain is positive and significant, consistent with those who are past their pension wealth peak being substantially more likely to retire; the retirement probability is almost doubled for those with negative pension gain. Surprisingly, the dummy on pension gain equal to zero is negative. Column 4 shows this specification with the relevant interactions with $K N O W \_S I G N$. In the lower half of Table 5, we illustrate the magnitudes of these estimated effects by calculating the probability of retirement for all combinations of $K N O W \_S I G N$ and whether pension gain is positive, zero, or negative. There are much larger differences between those with positive and negative pension gain values among the well-informed group, with probabilities ranging from 0.027 to 0.242 . In contrast, those who are not informed according to this measure show very little difference in retirement probabilities with pension gain. It is also worth noting that the main effect of this knowledge measure does not always serve to increase the probability of retirement. For individuals with a positive pension gain (i.e., those who can increase pension wealth by deferring retirement into the future), being knowledgeable actually reduces the probability of retirement from 0.068 to 0.027 . This provides evidence that at least some of the main effect of the information does not reflect a reverse causality in which individuals only become informed when they are on the verge of retirement.

In the next section, we further consider the appropriate interpretation of these results. 
However, if taken at face value, they suggest significant "mistakes" in retirement decisionmaking, as the result of misinformation. If the costs of obtaining information on one's pension are reasonably low, this raises questions about the value of the information. How costly is it, for example, to retire according to one's perceived pension incentive, rather than the true incentive? To address this, we calculate the difference in the present value of pension wealth (from the employer reports) if retirement occurs at the wealth maximizing age, versus the present value if retirement occurs at the self-reported wealth maximizing age (but using wealth values from the employer reports). While not all individuals will retire at the wealth maximizing age, this gives us a rough idea of the potential cost of responding to perceived pension incentives rather than the true incentives. For the full sample of individuals with both employer- and self-reports of pension values, the median difference in pension wealth calculated in this way is roughly $\$ 3,000$, or 3 percent of the maximum pension wealth from the employer reports. This, of course, includes very small differences for those who are well-informed. When we calculate this gap among the uninformed, the values are substantial. Among those with $K N O W \_G A I N=0$, the median reduction in maximum pension wealth from misinformation is $\$ 6,900$, or roughly 6 percent of pension wealth at the wealth maximizing age. The 75th percentile of this distribution is more than $\$ 20,000$, or 18 percent of pension wealth. Similarly, among those with $K N O W \_S I G N=0$, the median difference in pension wealth at the employer- and self-reported wealth maximizing ages is more than $\$ 9,000$, and the 75 th percentile difference is almost $\$ 24,000$. While it can be subjective to categorize magnitudes as large or small, it does not seem easy to dismiss these dollar amounts as economically unimportant. Individuals who do not have detailed pension information may stand to lose significant portions of their pension wealth. 


\section{Do Uninformed Individuals Respond to Perceived Incentives?}

One interpretation of the results thus far is that information can have powerful effects on individual behavior. We are cautious in reaching such a conclusion, however, since it is likely that at least some information acquisition is not exogenous to the retirement decision. One possible explanation for our finding of stronger responsiveness among the knowledgeable, for example, is that individuals might determine how much information to gather based on how likely they are to take account of that information in making retirement decisions. In this case, causality runs from dispersion in responsiveness to dispersion in knowledge and some individuals will be uninformed because they have no intention of taking financial incentives into account in choosing a retirement date.

This poses a challenge for estimation of causal effects, similar to the issues raised in the literature on estimating heterogeneous returns to education (see Card, 1999, for a discussion). Given the lack of any convincing instruments for pension knowledge in this situation, we cannot formally rule out this possibility. However, by considering the role that self-reported pension incentives play in retirement decisions, we are able to provide some evidence that this form of endogeneity is not driving our results. If it is simply the case that those who are responsive gather information, while those who are unresponsive do not (because information collection is costly and does not benefit them in any way), then the non-responders should not respond to any pension information, including their own self-reported information. We have shown above that misinformed individuals do not respond to the administratively reported pension incentive, but do these same misinformed individuals respond to their self-reported and objectively incorrect incentive? Or, are they simply nonresponsive to any incentive whatsoever?

Table 6 produces results analogous to those in Table 4, but focuses on self-reported 
pension information (rather than employer-reports) interacted with the knowledge measures.

The first column simply reproduces column 2 of Table 3, where we estimated the average effect of employer-reported pension gain on retirement for the sample with a self-reported pension gain. In the second column, we use self-reported pension gain, KNOW_GAIN, and their interaction. The coefficient on self-reported pension gain by itself, which reflects the responsiveness of misinformed individuals, is statistically significant and of similar magnitude to the average responsiveness to employer-reported pension gain in column 1. Thus, misinformed individuals nevertheless respond to their perceived incentive in making their retirement decisions. The better-informed group has a much larger response to self-reported pension gain, as shown by the interaction of KNOW_GAIN and pension gain. The results in the third column are even more striking: there is only a small difference in the responsiveness of informed and misinformed individuals to their own perceptions of pension gain when our measure of knowledge is simply whether they are aware of the sign of their incentive.

The results here are inconsistent with the misinformed not responding to pension information under any circumstances. Indeed, it is clear that they are responsive to their own perceived but incorrect information; people respond to what they know. From a policy perspective, this suggests that providing these individuals with the correct information could lead them to respond to their actual incentives.

\section{A Retirement Model with Selection into Knowledge States}

Another possible explanation for our finding of stronger responsiveness among the knowledgeable is that individuals do not actively collect information about their pensions until they are seriously considering retirement. If this is the case, unobserved characteristics may 
make individuals both more likely to be well-informed about their pensions, and more likely to retire. Combining this with a formulation in which there are (potential) differences in the determinants of retirement among the informed and uninformed, results in a model that can be written as:
a) $\quad R_{i t}=\gamma_{0}^{U}+\gamma_{1}^{U} G A I N_{i t}+\gamma_{2}^{U} X_{i t}+\varepsilon_{i t}^{U}$
if uninformed $\left(I N F O R M E D_{i t}=0\right)$
b) $\quad R_{i t}=\gamma_{0}^{K}+\gamma_{1}^{K} G A I N_{i t}+\gamma_{2}^{K} X_{i t}+\varepsilon_{i t}^{K}$
if informed (INFORMED $\left.D_{i t}=1\right)$

where INFORMED $D_{i t}$ is one of several binary variables indicating whether or not an individual is informed about his or her financial options as defined above, $X_{i t}$ and $Z_{i t}$ are vectors of variables that affect information acquisition, and $v_{i t}$ is an error term. Note that both GAIN and $X$ appears in [5] in predicting retirement, but that $Z$ is unique to [4]. ${ }^{14}$ If $v_{i t}$ is correlated with the $\varepsilon_{i t}$ terms, separate estimation of equations [4] and [5] will be subject to a standard selection bias. ${ }^{15}$ Most importantly, our estimates of $\gamma_{1}$ may be biased.

The major challenge in jointly estimating the system of equations [4] and [5] involves the separate identification of the knowledge and the retirement components. To estimate the parameters of the model consistently, we need to identify factors that: (i) help predict the individual knowledge of pension incentives, but that, (ii) do not also affect retirement

\footnotetext{
${ }^{14}$ We allow for the possibility that GAIN affects the extent of knowledge since models of information acquisition suggest that those with more potential benefit will be more likely to invest in information gathering.

${ }^{15}$ See Heckman (1976) and Lee (1976). A similar application of this type of selection model appears in Willis and Rosen (1979).
} 
decisions. ${ }^{16}$ Towards this end, we briefly consider what factors help determine an individual's level of pension knowledge.

Previous work provides some guidance. Mitchell (1988) identifies three broad sets of factors that should influence information acquisition in this setting. First, the abilities of individuals to process complex financial information may affect retention and understanding of their pension plans. Educational attainment and other individual characteristics fall into this category. Many of these characteristics may also affect retirement probabilities, for example, through correlation with tastes or preferences towards leisure, and so will not help in the separate identification of equations [4] and [5]. Nevertheless, it is important to understand how such characteristics affect knowledge since this will also tell us which segments of the population are most likely to respond strongly to pension incentives. One other factor in this category is whether an individual is covered by multiple pension plans. This could serve as a proxy for the complexity of the calculations required to summarize the financial incentives associated with alternative retirement dates. We include an indicator variable for this that is excluded from the retirement equation, and so contributes to the identification of the selection model.

A second set of factors that should influence pension knowledge involves firm-based differences in the efficiency of information dissemination. Focusing on variables that may indicate information dissemination by employers is one way to identify factors that are more likely to be exogenous to workers' retirement behavior. Specifically, larger firms may be more likely to have formal information programs, or at least human resources departments able to

\footnotetext{
${ }^{16}$ Non-linearities in functional form will also allow the model to be identified, but we have estimated the model using linear probability models for both the information and retirement equations and obtained very similar results.
} 
provide information systematically to their workers. ${ }^{17}$ There is little reason to think that, after conditioning on financial incentives and lifetime earnings, the size of a worker's firm should influence retirement. Union membership might similarly indicate the existence of an information-provision system for a given worker. Both Mitchell (1988) and Gustman and Steinmeier (2001c) find some evidence that unionized workers are better informed about their retirement incentives. Union status should not influence the retirement decision, as long as retirement incentives and other characteristics of the job that might alter the utility of leisure (physical demands of the job, for example) are controlled for. Fortunately, the HRS also contains a variety of measures of such job characteristics that we can include in the model and that allow us to exclude credibly a worker's union status from the retirement regressions. Finally, we include a variable indicating the time until an individual's retirement-wealth maximizing age based on the employer-reported pension data. The idea here is that firms will have an incentive to inform individuals of upcoming pension benefits as these individuals approach important "kinks" in their pension benefit schedules. Conditional on the private pension gain associated with a given year and the individual's age (entered non-linearly), the number of years before or after their optimum should not influence retirement. ${ }^{18}$

A third set of factors identified by Mitchell (and others) as influencing individual knowledge of pensions involves the benefit of that information: a greater likelihood of benefiting from knowledge of pension details should lead individuals to acquire more information. The

\footnotetext{
${ }^{17}$ Mitchell (1988) uses a measure of firm size in her analysis of the determinants of pension information, and does not find it to have a significant effect. She had information, however, only on the average firm size at the industry level while the HRS provides information on the actual firm size of the individual's employer.

${ }^{18}$ This is similar in spirit to Luchak and Gunderson's (1999) finding that individuals at or beyond their wealth maximizing age are more knowledgeable about pension benefits.
} 
size of the pension gain itself may be relevant here, as well as health status, job characteristics and the age and health of the individual and his or her spouse. As was the case with individual demographic characteristics, most of these factors will also affect the retirement decision.

Based on the above considerations, we estimate the model summarized by equations [4] and [5] using time left until the pension maximizing age from employer reports, and indicators for multiple pension plans, firm size, and union status as the variables excluded from the retirement equation in estimating the selection model.

Table 7 shows results for $K N O W \_G A I N$, and $K N O W \_S I G N$, in our probit estimates of [4] from joint estimation of [4] and [5]. ${ }^{19}$ Beginning with the variables included in both the knowledge and retirement equations (in the lower part of the table), a larger pension gain makes an individual more likely to be well-informed, consistent with theories suggesting that those with larger marginal benefits of information are more likely to gather that information. Black and Hispanic individuals are less well-informed than white non-Hispanics. The probability of knowing the sign of pension gain among blacks, for example, is 7 to 10 percentage points lower than that for comparable white individuals, while for Hispanics the reduction is approximately 5 percentage points. ${ }^{20}$ Education does not significantly increase the probability of being wellinformed, and actually decreases the probability of having a self-reported pension gain that is close in magnitude to that based on the employer reports $\left(K N O W_{-} G A I N=1\right)$. Health status and several job characteristics (whether the job is physically demanding, stressful, or difficult) also do not have consistent or significant effects on knowledge. There is evidence that men are better

\footnotetext{
${ }^{19}$ We have also estimated this model for REPORT and have obtained qualitatively similar results.

${ }^{20}$ These and subsequent marginal effects cited are calculated at the sample means of continuous variables, and for a white, male, non-union worker at a small firm with a high school education, unmarried and without multiple pension plans.
} 
informed about their pensions, regardless of the information measure used. There is also evidence of improved information as individuals age when $K N O W \_G A I N$ is the knowledge measure. The probability of being well-informed about one's pension gain rises by approximately 4.5 percentage points between ages 55 and $65 .^{21}$ In contrast, the probability of knowing the sign of one's pension gain actually declines significantly with age.

The variables in the top rows of Table 7 are those that we use to predict the knowledge measures but exclude from the retirement equation. Having multiple pension plans reduces the probability of being well-informed by 1 to 5 percentage points, but is statistically significant only for $K N O W \_G A I N$. Union members are 7 to 9 percentage points more likely to be aware of whether they have a gain, a loss, or no change in retirement wealth from deferring retirement. Surprisingly, the union variable is significant and negative in the equations predicting $K N O W_{-} G A I N$ : union members are roughly 4 percentage points less likely to know their pension gain. The firm size measures also have unexpected signs and are generally not statistically significant. Where they are significant, they suggest, contrary to our expectations, that those working for firms of greater than 100 employees are less well-informed about their pensions. Finally, the variable indicating years until an individual's pension-wealth-maximizing age is negative (as expected) and significant. Being one year closer to the wealth-maximizing retirement age makes individuals one to two percentage points more likely to be well-informed. The coefficients of the retirement probit from jointly estimating equations [4] and [5] are summarized in Table 8. The first two columns estimate a model of retirement in which

\footnotetext{
${ }^{21}$ Some of the relatively small effects of age are explained by our inclusion of the variable for time until the wealth maximizing age. When we eliminate this variable the probability of having $K N O W_{-} G A I N=1$ rises by almost 15 percentage points between ages 55 and 65 .
} 
KNOW_GAIN is used as the information measure. As expected given our earlier results, there are very different effects of pension gain among the informed and uninformed groups. For comparison, the lower half of the table shows results in which we estimate separate probit equations for the informed and uninformed group, but do not allow for correlation with the error term in the information equation. Among those with $K N O W \_G A I N=0$, there is not a significant effect of pension gain on the probability of retirement.

The results in columns 3 and 4 of Table 8 echo the results based on KNOW_GAIN. When KNOW_SIGN is used as our measure of pension knowledge, there continue to be large differences in the extent of responsiveness to pension gain. The difference in responsiveness between the informed and uninformed group is reduced by approximately one-third when we jointly estimate the equations. However, our overall conclusion of large differences in responsiveness between the informed and uninformed is unchanged.

In columns 5 and 6 of Table 8 we estimate a specification of the selection model that includes both a continuous pension gain variable, and a dummy for having pension gain less than or equal to zero. The corresponding coefficients from the information equation are shown in the third column of Table 7. This specification is motivated by our concern that individuals with non-positive pension gains may be both more likely to retire, and more likely to be wellinformed. If the relationships between pension gain, retirement, and the likelihood of becoming informed are highly non-linear, this could explain why the sample-selection correction makes little difference to our results. These results show that having pension gain less than or equal to zero is a strong predictor of both retirement and the extent of pension knowledge. The final column of Table 7 shows that having a non-positive pension gain actually makes individuals less-likely to be well-informed, after conditioning on the other covariates. In Table 8, however, 
we again find much larger effects of pension gain among the well-informed group.

In sum, our results appear robust to joint estimation of the determinants of information and retirement. They key caveat to this finding, of course, is that the results from this model depend upon our exclusion restrictions, our ability to separately identify the two equations in question. We find no evidence, however, that selection effects can explain away the greater responsiveness of well-informed individuals to their pension incentives. This is also consistent with our findings from Table 5, which indicate that knowledge does not always make individuals more likely to retire. Rather, knowledge that individuals should work longer (in the sense that they have financial gains to delaying retirement, or a positive pension gain) reduces retirement probabilities, while knowledge of negative pension gain increases retirement probabilities.

\section{Conclusion}

This paper documents the differential responsiveness to economic incentives by knowledge of those incentives in the case of retirement decision-making. Specifically, we have shown that there is important heterogeneity in how individuals consider financial factors in choosing a retirement date, and that this heterogeneity is directly related to individuals' level of knowledge about these financial factors. Two important policy issues are directly addressed: how do people respond to the information that they have, and will providing more information alter their behavior? We have shown that, rather than being unresponsive, misinformed individuals do respond to their perceived, but incorrect, pension information.

In the course of this study, we have demonstrated the usefulness of self-reported data as collected in the Health and Retirement Study and other surveys. Individuals respond directly to 
these self-reports, suggesting that they do capture the economic incentives that individuals perceive themselves to be facing. The self-reported pension data provide an important intermediate step between administrative reports of pensions and the retirement response of individuals. Instead of being substitutes for one another, the self- and administratively-reported data are complements in understanding individual responses to retirement incentives.

Our findings also have important implications for applied economic research that seeks to measure the responsiveness of individuals to certain incentives. At a minimum, they point to the need to think carefully about whether those incentives are properly known by the individuals who are assumed to be affected. For policy purposes, it is important to consider the role of information as a link between incentives and behavior, since information may not be held constant under alternative policy reforms. 


\section{References}

Bernheim, B. Douglas, and Daniel M. Garrett (1996) "The Determinants and Consequences of Financial Education in the Workplace: Evidence from a Survey of Households." NBER Working Paper 5667.

Card, David (1999) "The causal effect of education on earnings" in Handbook of Labor Economics Volume 3, Orley Ashenfelter and David Card, eds.

Chan, Sewin, and Ann Huff Stevens (2002) "How Does Job Loss Affect the Timing of Retirement?" NBER Working Paper 8780.

Chan, Sewin, and Ann Huff Stevens (2003) "Do Changes in Pension Incentives Affect Retirement? A Longitudinal Study of Subjective Retirement Expectations" Journal of Public Economics, forthcoming.

Choi, James J., David Laibson, Brigitte C. Madrian and Andrew Metrick (2001) "Defined Contribution Pensions: Plan Rules, Participant Decisions, and the Path of Least Resistance." NBER Working Paper 8655.

Coile, Courtney and Jonathan Gruber (2000) "Social Security and Retirement," NBER Working Paper 7830.

Duflo, Esther and Emmanuel Saez (2002) "Participation and Investment Decisions in a Retirement Plan: The Influence of Colleagues' Choices" Journal of Public Economics 85(1): 121-48.

Duflo, Esther and Emmanuel Saez (2002) "The Role of Information and Social Interactions in Retirement Plan Decisions: Evidence from a Randomized Experiment." NBER Working Paper 8885.

Gustman, Alan L., and Thomas L. Steinmeier (2001a) "What People Don't Know about their Pensions and Social Security" in William G. Gale, John B. Shoven and Mark J.

Warshawsky, editors, Public Policies and Private Pensions, Washington D.C.: Brookings Institution. (NBER Working Paper 7368.)

Gustman, Alan L., and Thomas L. Steinmeier (2001b) "Retirement and Wealth," Social Security Bulletin, Perspectives, Vol. 65 No.3, forthcoming. (NBER Working Paper 8229.)

Gustman, Alan L., and Thomas L. Steinmeier (2001c) "Imperfect Knowledge, Retirement and Saving," NBER Working Paper 8406.

Heckman, James J. (1976) “The Common Structure of Statistical Models of Truncation, Sample 
Selection, and Limited Dependent Variables and a Simple Estimator for Such Models." Annals of Economic and Social Measurement 5 Fall: 475-92.

Lee, Lung Fei. "Estimation of Limited Dependent Variables Models by Two-Stage Methods." Ph.D. Dissertation, University of Rochester, 1976.

Luchak, Andrew, and Morley Gunderson (2000) "What Do Employees Know About their Pension Plan?" Industrial Relations 39:4, 646-670.

Lumsdaine, Robin, James Stock and David Wise (1992) "Three Models of Retirement: Computational Complexity Versus Predictive Validity," in Topics in the Economics of Aging, David Wise, ed. Chicago: University of Chicago Press.

Mitchell, Olivia (1988) “Worker Knowledge of Pension Provisions," Journal of Labor Economics 6:1, 21-39.

Samwick, Andrew (1998) "New Evidence on Pensions, Social Security, and the Timing of Retirement," Journal of Public Economics 70:2, 207-36.

Stock, James and David Wise (1990) "Pensions, the Option Value of Work, and Retirement," Econometrica 58: 1151-1180.

Uccello, Cori, and Kevin Perese (1999) "Wealth Accumulation in the Health and Retirement Study: The Importance of Including Pension Wealth,” Urban Institute Report.

Willis, Robert J. and Sherwin Rosen (1979) "Education and Self-Selection" Journal of Political Economy 87:s7-s36. 
Table 1

Sample Summary Statistics

\begin{tabular}{|c|c|c|c|}
\hline & Fraction & Mean & Standard deviation \\
\hline Retired this year & 0.13 & & \\
\hline Retired by end of sample & 0.34 & & \\
\hline Male & 0.53 & & \\
\hline Hispanic & 0.05 & & \\
\hline Black & 0.16 & & \\
\hline Married & 0.78 & & \\
\hline Age & & 58.3 & 3.5 \\
\hline Total non-pension assets \$ & & 277,655 & 688,461 \\
\hline Average Lifetime Earnings \$ & & 23,385 & 11,836 \\
\hline Pension wealth if retire immediately (self-report) $\$$ & & 68,794 & 290,577 \\
\hline Pension wealth if retire immediately (employer-report) $\$$ & & 153,218 & 251,503 \\
\hline Pension gain (self-report) $\$$ & & 56,534 & 154,064 \\
\hline Pension gain (employer-report) \$ & & 25,152 & 46,813 \\
\hline Number of observations & & 8,471 & \\
\hline
\end{tabular}

Notes: Pooled data from waves 1-4 of the Health and Retirement Study (HRS).

The sample includes all HRS respondents for whom there is an employer-reported pension at wave 1. Further details are given in section I of the text. 
Table 2

Measures of Knowledge

Sample:

Full

With a With no

DB plan DB plan

Fraction reporting key values of pension $(R E P O R T=1)$

$0.63 \quad 0.68 \quad 0.56$

Among those reporting key values of pension:

Fraction with $K N O W \_L E V E L=1$

$\begin{array}{lll}0.51 & 0.55 \quad 0.43\end{array}$

(ratio of employer to self- reported level of pension wealth is between 0.5 and 2)

Fraction with $K N O W \_G A I N=1$

$\begin{array}{lll}0.27 & 0.20 \quad 0.42\end{array}$

(ratio of employer to self- reported level of pension gain is between 0.5 and 2)

$\begin{array}{lll}0.55 & 0.59 \quad 0.49\end{array}$

(employer and self- reported pension gain is of the same sign.)

Fraction reporting expected Social Security benefits

$0.40 \quad 0.42 \quad 0.32$

Among those reporting expected Social Security benefits:

Fraction with $K N O W \_S S=1$

$\begin{array}{lll}0.77 & 0.75 \quad 0.79\end{array}$

( ratio of SSA- to self- reported expected SS benefits between 0.5 and 2.)

Number of observations

$8,471 \quad 5,207$

3,264

Notes: Pooled data from waves 1-4 of the Health and Retirement Study (HRS).

The sample includes all HRS respondents for whom there is an employer-reported pension at wave 1 .

Further details are given in section I of the text. 
Table 3

The Effect of Self- and Employer-Reported Pension Gain on the Annual Probability of Retirement

Dependent Variable:

Sample:

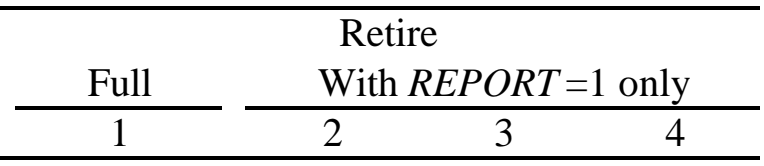

Pension gain based on employer-report

$\begin{array}{cc}-0.0179 & -0.0190 \\ (0.0080) & (0.0093) \\ -0.0025 & -0.0027 \\ & \\ 0.0054 & 0.0049 \\ (0.0013) & (0.0015) \\ 0.0007 & 0.0007\end{array}$

$-0.0179$

$-0.0190$

$-0.0168$

$(0.0098)$

$-0.0024$

Pension wealth level based on employer-report

Pension gain based on self-report

$-0.0213-0.0228$

(0.0029) (0.0027)

$-0.0034-0.0032$

Pension wealth level based on self-report

$0.0014 \quad 0.0010$

$(0.0011) \quad(0.0010)$

$0.0002 \quad 0.0001$

Correlation(pension gain based on employer-report, pension gain based on self-report)

Correlation(pension wealth level based on employer-report, 0.21 pension wealth level based on self-report)

\begin{tabular}{lllll}
\hline Number of observations & 8,471 & 5,368 & 5,368 & 5,368 \\
\hline
\end{tabular}

Notes: Probit coefficients estimated using data from waves 1-4 of the HRS. Standard errors are in ( ). The marginal effect of a $\$ 10,000$ increase in the variable (calculated for a 60-year old, married, white male, with some college education, observed in wave 2, and with all continuous variables set to their mean values) is shown in italics below the standard errors.

The sample in columns 2-4 include only those for whom a self-reported pension gain can be calculated. Pension gain and wealth levels are in $\$ 10,000$ s.

Other explanatory variables include race, education, health, marital status, non-pension assets, age, gender, wave, lifetime earnings and an intercept. 
Table 4

The Effect of Pension Gain and Knowledge on the Annual Probability of Retirement

\begin{tabular}{|c|c|c|c|c|c|c|c|c|}
\hline \multirow{3}{*}{$\begin{array}{l}\text { Dependent Variable: } \\
\text { Sample: }\end{array}$} & \multicolumn{8}{|c|}{ Retire } \\
\hline & \multicolumn{4}{|c|}{ Full } & \multicolumn{2}{|c|}{$\begin{array}{c}\text { Self-reporting SS } \\
\text { benefits only }\end{array}$} & \multicolumn{2}{|c|}{ DB only } \\
\hline & 1 & 2 & 3 & 4 & 5 & 6 & 7 & 8 \\
\hline Pension gain & $\begin{array}{l}-0.0179 \\
(0.0080)\end{array}$ & $\begin{array}{l}-0.0179 \\
(0.0170)\end{array}$ & $\begin{array}{l}-0.0120 \\
(0.0097)\end{array}$ & $\begin{array}{l}-0.0046 \\
(0.0078)\end{array}$ & & & $\begin{array}{l}-0.0222 \\
(0.0087)\end{array}$ & $\begin{array}{l}-0.0090 \\
(0.0088)\end{array}$ \\
\hline $\begin{array}{l}R E P O R T=1 \\
(R E P O R T=1) * \text { Pension gain }\end{array}$ & & $\begin{array}{c}0.2520 \\
(0.0604) \\
-0.0030 \\
(0.0186)\end{array}$ & & & & & & \\
\hline $\begin{array}{l}K N O W \_L E V E L=1 \\
\left(K N O W \_L E V E L=1\right)^{*} \text { Pension gain }\end{array}$ & & & $\begin{array}{c}0.1288 \\
(0.0668) \\
-0.0123 \\
(0.0152)\end{array}$ & & & & & \\
\hline $\begin{array}{l}K N O W \_G A I N=1 \\
\left(K N O W_{-} G A I N=1\right) * \text { Pension gain }\end{array}$ & & & & $\begin{array}{l}0.2636 \\
(0.0661) \\
-0.0950 \\
(0.0323)\end{array}$ & & & & $\begin{array}{c}0.2795 \\
(0.0881) \\
-0.0996 \\
(0.0356)\end{array}$ \\
\hline Pension and Social Security gain & & & & & $\begin{array}{l}-0.0113 \\
(0.0060)\end{array}$ & $\begin{array}{l}-0.0074 \\
(0.0119)\end{array}$ & & \\
\hline $\begin{array}{l}K N O W \_S S=1 \\
\begin{array}{r}\left(K N O W \_S S=1\right)^{*} \text { Pension and } \\
\text { Social Security gain }\end{array}\end{array}$ & & & & & & $\begin{array}{c}0.0401 \\
(0.1915) \\
-0.0047 \\
(0.0124)\end{array}$ & & \\
\hline Effect of $\$ 10,000$ increase in pensic & ain: & & & & & & & \\
\hline $\begin{array}{l}\text { average } \\
\text { uninformed } \\
\text { informed }\end{array}$ & -0.0025 & $\begin{array}{l}-0.0026 \\
-0.0031\end{array}$ & $\begin{array}{l}-0.0018 \\
-0.0036\end{array}$ & $\begin{array}{l}-0.0006 \\
-0.0136\end{array}$ & -0.0013 & $\begin{array}{l}-0.0009 \\
-0.0014\end{array}$ & -0.0031 & $\begin{array}{l}-0.0012 \\
-0.0149\end{array}$ \\
\hline $\begin{array}{l}\text { Change in P(retire) due to } \\
\text { main effect of informed: }\end{array}$ & & 0.0436 & 0.0211 & 0.0436 & & 0.0044 & & 0.0468 \\
\hline Number of observations & 8,471 & 8,471 & 8,471 & 8,471 & 3,341 & 3,341 & 5,207 & 5,207 \\
\hline
\end{tabular}

Notes: Probit coefficients estimated using data from waves 1-4 of the HRS. Standard errors are in ( ).

The marginal effect of a $\$ 10,000$ increase in pension gain and the change in probability of retirement is calculated for a 60 -year old, married, white male, with some college education, observed in wave 2, and with all continuous variables set to their mean values.

Pension gain is in $\$ 10,000$ s and are based on employer-reports.

Other explanatory variables include pension wealth, race, education, health, marital status, non-pension assets, age, gender, wave, lifetime earnings and an intercept. 
Table 5

The Effect of Knowing the Sign of Pension Gain on the Annual Probability of Retirement

\begin{tabular}{|c|c|c|c|c|}
\hline \multirow[t]{2}{*}{$\begin{array}{l}\text { Dependent Variable: } \\
\text { Sample: }\end{array}$} & \multicolumn{4}{|c|}{$\begin{array}{l}\text { Retire } \\
\text { Full }\end{array}$} \\
\hline & 1 & 2 & 3 & 4 \\
\hline Pension gain & $\begin{array}{l}-0.0179 \\
(0.0080)\end{array}$ & $\begin{array}{c}0.0046 \\
(0.0079)\end{array}$ & & \\
\hline$K N O W \_S I G N=1$ & & $\begin{array}{c}0.1703 \\
(0.0558)\end{array}$ & & $\begin{array}{l}-0.4407 \\
(0.0625)\end{array}$ \\
\hline$\left(K N O W \_S I G N=1\right) *$ Pension gain & & $\begin{array}{l}-0.0960 \\
(0.0193)\end{array}$ & & \\
\hline Pension gain $=0$ & & & $\begin{array}{c}-0.1241 \\
(0.0654)\end{array}$ & $\begin{array}{l}-0.4622 \\
(0.0825)\end{array}$ \\
\hline Pension gain $<0$ & & & $\begin{array}{c}0.4274 \\
(0.0590)\end{array}$ & $\begin{array}{c}0.1185 \\
(0.0684)\end{array}$ \\
\hline$\left(K N O W \_S I G N=1\right)$ and $($ Pension gain $=0)$ & & & & $\begin{array}{c}0.9927 \\
(0.1371)\end{array}$ \\
\hline$\left(K N O W \_S I G N=1\right)$ and $($ Pension gain $<0)$ & & & & $\begin{array}{r}1.1129 \\
(0.1137)\end{array}$ \\
\hline
\end{tabular}

$\mathrm{P}$ (retire) for $K N O W \_S I G N=1$ :

$\begin{array}{ll}\text { employer reported pension gain }>0 & 0.0268\end{array}$

$\begin{array}{ll}\text { employer reported pension gain }=0 & 0.0807\end{array}$

$\begin{array}{ll}\text { employer reported pension gain }<0 & 0.2422\end{array}$

$\mathrm{P}($ retire $)$ for $K N O W \_S I G N=0$ :

$\begin{array}{ll}\text { employer reported pension gain }>0 & 0.0681\end{array}$

$\begin{array}{ll}\text { employer reported pension gain }=0 & 0.0255\end{array}$

employer reported pension gain $<0 \quad 0.0851$

\begin{tabular}{lllll}
\hline Number of observations & 8,471 & 8,471 & 8,471 & 8,471 \\
\hline
\end{tabular}

Notes: Probit coefficients estimated using data from waves 1-4 of the HRS. Standard errors are in ( ). Pension gain is in $\$ 10,000$ s and are based on employer-reports.

Other explanatory variables include pension wealth, race, education, health, marital status, non-pension assets, age, gender, wave, lifetime earnings and an intercept. 
Table 6

The Effect of Self-Reported Pension Gain and Knowledge on the Annual Probability of Retirement

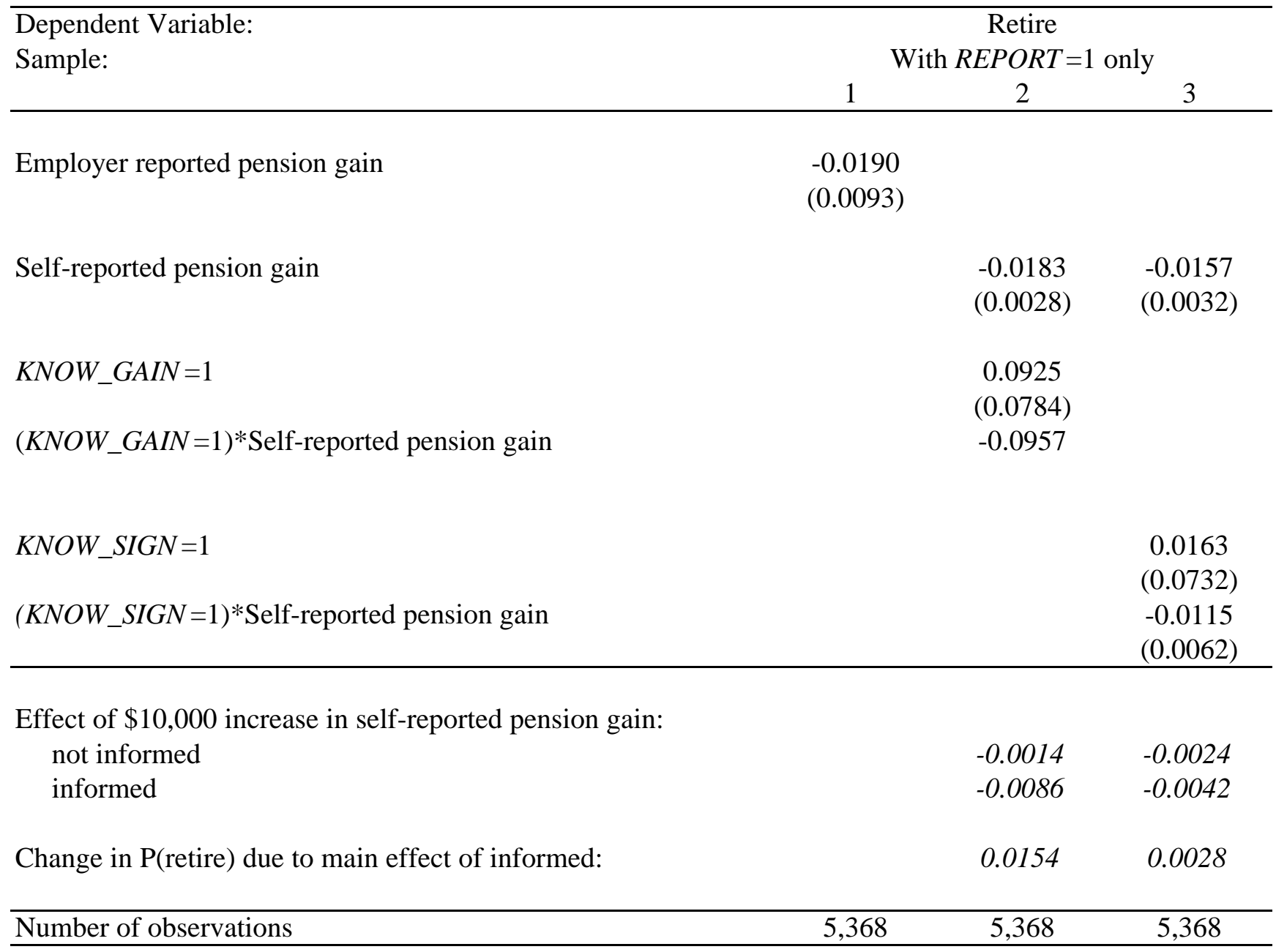

Notes: Probit coefficients estimated using data from waves 1-4 of the HRS. Standard errors are in ( ). The sample includes only those for whom a self-reported pension gain can be calculated.

The marginal effect of a $\$ 10,000$ increase in pension gain and the change in probability of retirement is calculated for a 60-year old, married, white male, with some college education, observed in wave 2 , and with all continuous variables set to their mean values.

Self- and employer-reported pension gain are in $\$ 10,000$ s.

Other explanatory variables include pension wealth, race, education, health, marital status, non-pension assets, age, gender, wave, lifetime earnings and an intercept. 
Table 7

Determinants of Pension Knowledge

\begin{tabular}{|c|c|c|c|}
\hline \multirow[t]{2}{*}{$\begin{array}{l}\text { Dependent Variable } \\
\text { Sample: }\end{array}$} & KNOW_GAIN & Full & KNOW_SIGN \\
\hline & 1 & 2 & 3 \\
\hline \multicolumn{4}{|l|}{ Excluded from retirement equation: } \\
\hline \multirow[t]{3}{*}{ Multiple pension plans } & -0.1515 & -0.0178 & -0.0328 \\
\hline & $(0.0627)$ & $(0.0442)$ & $(0.0540)$ \\
\hline & -0.0494 & -0.0069 & -0.0130 \\
\hline \multirow[t]{3}{*}{ Union member } & -0.1725 & 0.1805 & 0.2168 \\
\hline & $(0.0618)$ & $(0.0581)$ & $(0.0511)$ \\
\hline & -0.0558 & 0.0719 & 0.0862 \\
\hline \multirow[t]{3}{*}{ Union status missing } & 0.0236 & -0.0644 & -0.0469 \\
\hline & $(0.2091)$ & $(0.1274)$ & $(0.1795)$ \\
\hline & & -0.0251 & -0.0186 \\
\hline \multirow[t]{3}{*}{ Firm size $>100 \&<500$} & 0.0129 & -0.0191 & -0.0301 \\
\hline & $(0.0701)$ & $(0.0482)$ & $(0.0597)$ \\
\hline & 0.0044 & -0.0075 & -0.0120 \\
\hline \multirow[t]{3}{*}{ Firm size $>500$} & -0.1936 & -0.0073 & -0.0185 \\
\hline & $(0.0690)$ & $(0.0455)$ & $(0.0566)$ \\
\hline & -0.0622 & -0.0029 & -0.0073 \\
\hline \multirow[t]{3}{*}{ Firm size missing } & 0.2995 & 0.1120 & 0.2365 \\
\hline & $(0.1843)$ & $(0.1165)$ & $(0.1800)$ \\
\hline & 0.1095 & 0.0443 & 0.0940 \\
\hline \multirow[t]{3}{*}{ Time to pension maximizing age } & -0.0261 & -0.0319 & -0.0455 \\
\hline & $(0.0083)$ & $(0.0060)$ & $(0.0073)$ \\
\hline & -0.0089 & -0.0124 & -0.0182 \\
\hline \multicolumn{4}{|l|}{ Not excluded from retirement equation: } \\
\hline \multirow[t]{3}{*}{ Pension Gain } & 0.0208 & 0.0291 & 0.0173 \\
\hline & $(0.0065)$ & $(0.0079)$ & $(0.0076)$ \\
\hline & 0.0071 & 0.0113 & 0.0069 \\
\hline \multirow[t]{3}{*}{ Pension Gain $<=0$} & & & -0.3690 \\
\hline & & & $(0.0753)$ \\
\hline & & & -0.1419 \\
\hline \multirow[t]{3}{*}{ Pension wealth } & -0.0003 & 0.0018 & 0.0021 \\
\hline & $(0.0011)$ & $(0.0015)$ & $(0.0014)$ \\
\hline & -0.0001 & 0.0007 & 0.0008 \\
\hline \multirow[t]{3}{*}{ Hispanic } & -0.1134 & -0.1224 & -0.1372 \\
\hline & $(0.1307)$ & $(0.1132)$ & $(0.1131)$ \\
\hline & -0.0374 & -0.0473 & -0.0542 \\
\hline Black & -0.2068 & -0.2755 & -0.2904 \\
\hline & $(0.0826)$ & $(0.0683)$ & $(0.0681)$ \\
\hline & -0.0662 & -0.1039 & -0.1129 \\
\hline Some college & 0.0093 & -0.0101 & 0.0026 \\
\hline & $(0.0719)$ & $(0.0633)$ & $(0.0633)$ \\
\hline & 0.0032 & -0.0040 & 0.0011 \\
\hline College graduate & -0.1905 & 0.0157 & 0.0269 \\
\hline & $(0.0701)$ & $(0.0640)$ & $(0.0637)$ \\
\hline & -0.0609 & 0.0062 & 0.0107 \\
\hline Married & 0.0741 & 0.0345 & 0.0341 \\
\hline & $(0.0706)$ & $(0.0601)$ & $(0.0601)$ \\
\hline & 0.0247 & 0.0135 & 0.0136 \\
\hline Non-pension assets & -0.0068 & -0.0079 & -0.0077 \\
\hline & $(0.0062)$ & $(0.0049)$ & $(0.0049)$ \\
\hline & -0.0023 & -0.0031 & -0.0031 \\
\hline Average lifetime earnings & 0.1296 & 0.2139 & 0.2415 \\
\hline & $(0.3078)$ & $(0.2550)$ & $(0.2569)$ \\
\hline & 0.0441 & 0.0834 & 0.0966 \\
\hline Lifetime earnings missing & -0.1282 & -0.1256 & -0.1251 \\
\hline & $(0.1015)$ & $(0.0842)$ & $(0.0846)$ \\
\hline & -0.0421 & -0.0485 & -0.0495 \\
\hline Male & 0.1637 & 0.1958 & 0.2046 \\
\hline & $(0.0667)$ & $(0.0562)$ & $(0.0568)$ \\
\hline & 0.0582 & 0.0777 & 0.0814 \\
\hline Wave 3 & -0.1261 & -0.1581 & -0.1653 \\
\hline & $(0.0386)$ & $(0.0337)$ & $(0.0341)$ \\
\hline & -0.0414 & -0.0608 & -0.0652 \\
\hline
\end{tabular}




\begin{tabular}{|c|c|c|c|}
\hline \multirow[t]{3}{*}{ Wave 4} & -0.0991 & -0.2602 & -0.2439 \\
\hline & (0.0709) & $(0.0717)$ & $(0.0697)$ \\
\hline & -0.0328 & -0.0984 & -954.0000 \\
\hline \multirow[t]{3}{*}{ Age 54} & -0.0567 & 0.0298 & 0.0103 \\
\hline & $(0.0677)$ & $(0.0591)$ & $(0.0592)$ \\
\hline & -0.0209 & 0.0119 & 0.0041 \\
\hline \multirow[t]{3}{*}{ Age 55} & -0.2150 & -0.1320 & -0.1569 \\
\hline & $(0.0823)$ & $(0.0718)$ & (0.0719) \\
\hline & -0.0762 & -0.0523 & -0.0625 \\
\hline \multirow[t]{3}{*}{ Age 56} & -0.2631 & -0.1517 & -0.1692 \\
\hline & (0.0914) & $(0.0795)$ & $(0.0794)$ \\
\hline & -0.0921 & -0.0601 & -0.0674 \\
\hline \multirow[t]{3}{*}{ Age 57} & -0.2763 & -0.1116 & -0.1377 \\
\hline & $(0.0970)$ & $(0.0838)$ & $(0.0842)$ \\
\hline & -0.0964 & -0.0443 & -0.0548 \\
\hline \multirow[t]{3}{*}{ Age 58} & -0.2434 & -0.1515 & -0.1898 \\
\hline & $(0.0975)$ & $(0.0856)$ & $(0.0861)$ \\
\hline & -0.0856 & -0.0600 & -0.0756 \\
\hline \multirow[t]{3}{*}{ Age 59} & -0.2807 & -0.1646 & -0.2113 \\
\hline & $(0.1016)$ & (0.0887) & $(0.0895)$ \\
\hline & -0.0978 & -0.0651 & -0.0841 \\
\hline \multirow[t]{3}{*}{ Age 60} & -0.1833 & -0.1472 & -0.1927 \\
\hline & $(0.1030)$ & $(0.0913)$ & $(0.0924)$ \\
\hline & -0.0655 & -0.0583 & -0.0767 \\
\hline \multirow[t]{3}{*}{ Age 61} & -0.1196 & -0.1654 & -0.1971 \\
\hline & $(0.1065)$ & (0.0947) & (0.0957) \\
\hline & -0.0434 & -0.0654 & -0.0785 \\
\hline \multirow[t]{3}{*}{ Age 62} & -0.0780 & -0.2985 & -0.3335 \\
\hline & $(0.1090)$ & $(0.0970)$ & $(0.0984)$ \\
\hline & -0.0285 & -0.1165 & -0.1323 \\
\hline \multirow[t]{3}{*}{ Age 63} & -0.0447 & -0.2996 & -0.3274 \\
\hline & (0.1159) & $(0.1040)$ & $(0.1051)$ \\
\hline & -0.0165 & -0.1170 & -0.1299 \\
\hline \multirow[t]{3}{*}{ Age 64} & -0.0393 & -0.3193 & -0.3615 \\
\hline & $(0.1292)$ & $(0.1168)$ & $(0.1179)$ \\
\hline & -0.0145 & -0.1243 & -0.1432 \\
\hline \multirow[t]{3}{*}{ Age 65} & -0.0866 & -0.6004 & -0.6215 \\
\hline & $(0.1456)$ & $(0.1357)$ & $(0.1386)$ \\
\hline & -0.0316 & -0.2230 & -0.2401 \\
\hline \multirow[t]{3}{*}{ Age 66} & 0.1486 & -0.4832 & -0.4808 \\
\hline & $(0.1715)$ & $(0.1647)$ & $(0.1685)$ \\
\hline & 0.0566 & -0.1836 & -0.1888 \\
\hline \multirow[t]{3}{*}{ Age 67 or older } & 0.2246 & -0.3867 & -0.3658 \\
\hline & $(0.2091)$ & $(0.1969)$ & $(0.2022)$ \\
\hline & 0.0864 & -0.1492 & -0.1449 \\
\hline \multirow[t]{3}{*}{ Poor health } & 0.0687 & 0.0228 & 0.0250 \\
\hline & $(0.0708)$ & $(0.0656)$ & $(0.0668)$ \\
\hline & 0.0239 & 0.0089 & 0.0099 \\
\hline \multirow[t]{3}{*}{ Job is physically demanding } & -0.0415 & -0.0633 & -0.0759 \\
\hline & $(0.0390)$ & $(0.0337)$ & $(0.0341)$ \\
\hline & -0.0140 & -0.0246 & -0.0301 \\
\hline Job is difficult & -0.0552 & 0.0553 & 0.0466 \\
\hline & $(0.0385)$ & $(0.0337)$ & $(0.0344)$ \\
\hline & -0.0185 & 0.0218 & 0.0186 \\
\hline Job is stressful & -0.0282 & -0.0303 & -0.0389 \\
\hline & $(0.0382)$ & $(0.0339)$ & $(0.0346)$ \\
\hline & -0.0096 & -0.0119 & -0.0154 \\
\hline Constant & -0.5571 & -0.2367 & -0.0057 \\
\hline & $(0.1596)$ & $(0.1266)$ & $(0.1444)$ \\
\hline ber of observations & 8,471 & 8,471 & 8,471 \\
\hline
\end{tabular}

Notes: Probit coefficients jointly estimated with the selection model in Table 8 using data from waves 1-4 of the HRS. Standard errors are in ( ).

Marginal effects for continuous variables, and the change in probability resulting from a change in dummy variables are shown in italics below the standard errors.

Pension gain and wealth levels are in $\$ 10,000$ s and are based on employer-reports. 
Table 8

The Effect of Pensions on Retirement with Selection into Knowledge States

\begin{tabular}{lcccccccc}
\hline Dependent Variable: & \multicolumn{4}{c}{ Retire } \\
Measure of INFORMED : & \multicolumn{2}{c}{ KNOW_GAIN } & & \multicolumn{2}{c}{ KNOW_SIGN } & & \multicolumn{2}{c}{ KNOW_SIGN } \\
Value of INFORMED : & $=1$ & $=0$ & & $=1$ & $=0$
\end{tabular}

Selection model:

Pension Gain

$\begin{array}{lccccc}-0.126 & 0.003 & -0.062 & -0.001 & -0.0225 & -0.012 \\ (0.032) & (0.008) & (0.016) & (0.008) & (0.013) & (0.050)\end{array}$

Pension Gain $<=0$

$\begin{array}{ll}0.845 & -0.167\end{array}$

$(0.150) \quad(0.098)$

\section{Model without selection:}

$\begin{array}{lcccccc}\text { Pension Gain } & -0.126 & 0.000 & -0.099 & 0.007 & -0.020 & -0.004 \\ & (0.032) & (0.008) & (0.020) & (0.008) & (0.015) & (0.010)\end{array}$

Pension Gain <=0

$0.885 \quad-0.213$

$(0.108) \quad(0.068)$

\begin{tabular}{lccc}
\hline Number of observations & 8,471 & 8,471 & 8,471 \\
\hline
\end{tabular}

Notes: Probit coefficients estimated using data from waves 1-4 of the HRS. Standard errors are in ( ) Pension gain is in $\$ 10,000$ s and are based on employer-reports.

Selection model is jointly estimated with Table 7.

Model without selection is separate probits for individuals with INFORMED $=1$ and INFORMED $=0$. Other explanatory variables include those listed for Table 7 as "included in the retirement equation". 